\title{
Pemanfaatan Pekarangan Rumah untuk Budidaya Potok (Etlingera elatior) sebagai Bumbu Masak Lokal Kaya Antioksidan di Kelurahan Kereng Bangkirai, Kota Palangka Raya
}

\author{
Ni Nyoman Sri Yuliani*, Francisca Diana Alexandra, Indria Augustina, \\ Nawan, Syamsul Arifin, Tri Widodo, Septi Handayani, \\ Ashari Mohpul, Mikko Uriamapas Ludjen \\ Program Studi Pendidikan Dokter, Fakultas Kedokteran, Universitas Palangka Raya \\ Kampus UPR Tunjung Nyaho Jln. H.Timang Palangka Raya 73111 \\ * Penulis Korespodensi : nyomigiziklinik@gmail.com
}

\begin{abstract}
Potok (Etlingera elatior) benefits and potential to increase body immunity can be used as an alternative source of antioxidant-rich foods. The benefits of potok to increase immunity, especially during the Covid-19 pandemic, have not been widely known by the people of Central Kalimantan, especially in the city of Palangka Raya. Increasing endurance, people prefer to consume vitamins and herbs Kalimantan. The people of Kereng Bangkirai, as the FK UPR fostered area, do not yet know the benefits of potok for health, so not many are interested in planting this plant.Community service activities by FK UPR will carry out health education programs and the benefits of potok to increase body immunity as well as various methods of processing and cultivation of potok plant seeds to the community or family in Kereng Bangkirai. This activity was carried out with a total of 20 participants from Kereng Bangkirai Village. The results showed an increase in people's knowledge about the antioxidant content of Potok for Health and an increase in skills in cultivating potok plants.
\end{abstract}

Keywords : potok, Etlingera elatior, immunity, cultivation

\begin{abstract}
Abstrak
Manfaat dan potensi Potok (Etlingera elatior) untuk meningkatkan imunitas tubuh dapat digunakan sebagai alternatif sumber makanan kaya antioksidan. Manfaat potok untuk meningkatkan imunitas terutama di masa pandemi Covid-19, belum banyak diketahui oleh masyarakat Kalimantan Tengah khususnya di kota Palangka Raya. meningkatkan daya tahan tubuh, masyarakat lebih memilih mengkonsumsi vitamin dan herbal Kalimantan. Masyarakat Kereng Bangkirai sebagai wilayah binaan FK UPR belum mengetahui manfaat potok untuk kesehatan sehingga tidak banyak yang berminat menanam tanaman ini. Kegiatan Pengabdian kepada masyarakat oleh FK UPR akan melakukan program edukasi kesehatan dan manfaat potok untuk meningkatkan imunitas tubuh serta ragam cara pengolahannya serta budidaya bibit tanaman potok kepada masyarakat/ keluarga di Kereng Bangkirai. Kegiatan ini dilaksanakan dengan jumlah peserta sebanyak 20 orang yang berasal dari kelurahan Kereng Bangkirai. Hasil kegiatan didapatkan bahwa terjadi peningkatan pengetahuan masyarakat tentang kandungan antioksidan Potok bagi kesehatan dan peningkatan keterampilan dalam membudidayakan tanaman potok.
\end{abstract}

Kata kunci: potok, imunitas, budidaya

\section{PENDAHULUAN}

Pandemi Coronavirus Disease (COVID19) yang melanda seluruh dunia dan menyebar ke Indonesia, sehingga menimbulkan masalah kesehatan dan kematian yang sangat serius. Perkembangan kasus COVID-19 berdasarkan sumber data The World Health Organization (WHO) dan PHEOC Kemenkes RI tanggal 22
September 2020, total kasus COVID-19 secara global mencapai 31.174.627 kasus dengan kematian 962.613 kasus. Situasi di Indonesia sendiri, kasus COVID - 19 terkonfirmasi 252.923 dengan angka kematian mencapai 9,837 kasus dan data ini terus bertambah. Keadaan ini diantisipasi oleh pemerintah Indonesia dengan cara menerapkan langkahlangkah pencegahan penularan COVID-19. 
Penerapan upaya pencegahan penyebaran COVID-19 dilakukan dengan cara melakukan hygiene, sering mencuci tangan, melakukan desinfeksi, menggunakan alat pelindung diri dan mempersiapkan daya tahan tubuh yang baik (1). Dalam upaya meningkatkan daya tahan tubuh, masyarakat direkomendasikan mengkonsumsi makanan bergizi seimbang, sumber vitamin $A$, vitamin $C$, vitamin $E$, vitamin $B$, vitamin $D$, mineral dan antioksidan $(2,3)$. Usaha untuk meningkatkan daya tahan tubuh, menyebabkan masyarakat banyak membeli suplemen vitamin dan antioksidan sehingga membuat harga obat tersebut relatif naik dan lebih mahal dari harga normal.

Pemenuhan kebutuhan vitamin dan antioksidan yang terbaik adalah yang bersumber dari bahan makanan segar (4). Vitamin dan antioksidan untuk meningkatkan daya tahan tubuh banyak ditemukan dalam buah dan bumbu masak, contohnya buah kaya vitamin A,B,C dan E seperti jambu, jeruk, anggur hitam, alpukat, pepaya dan sebagainya. Bumbu masak yang mengandung antioksidan contohnya jahe, kunyit, bawang, bubuk cabai, temulawak dan masih banyak pilihan lainnya (5). Kalimantan tengah memiliki tanaman bumbu masak lokal yang berpotensi tinggi meningkatkan imunitas tubuh, salah satunya yang sering digunakan adalah Potok (Etlingera elatior). Berdasarkan kebiasaan masyarakat Kalimantan Tengah, Potok digunakan sebagai campuran dalam memasak lauk ikan sungai sehingga menciptakan rasa dan wangi yang khas. Hasil penelitian menyebutkan bahwa Potok atau E. elatior memiliki kandungan antioksidan yang dapat meningkatkan imunitas tubuh (6). Kandungan antioksidan dalam potok adalah flavonoid, tannin, terpenoid, saponin dan essential oil (7). Kandungan flavonoid yang tinggi dalam buah dan bunga potok memberikan efek menstimulasi imunitas tubuh dengan cara meningkatkan aktivitas fagositosis, stimulasi dan proliferasi limfokin serta sebagai penangkap radikal bebas dalam tubuh $(6,7)$. Secara in vitro, kandungan tannin dalam bunga potok memiliki efek antibakteri terhadap bakteri gram positif dan kandungan saponin di dalamnya digunakan sebagai ekspektoran (8). Manfaat dan potensi Potok untuk meningkatkan imunitas tubuh dapat digunakan sebagai alternatif sumber makanan kaya antioksidan. Manfaat Potok untuk meningkatkan imunitas terutama di masa pandemic Covid-19, belum banyak diketahui oleh masyarakat Kalimantan Tengah khususnya di kota Palangka Raya.

Kegiatan Pengabdian kepada Masyarakat ini dilakukan di Kelurahan Kereng Bangkirai, kelurahan ini sebagai salah satu wilayah binaan Fakultas Kedokteran Universitas Palangka Raya memiliki kelompok PKK yang memanfaatkan lahan pekarangan untuk menanam tanaman obat. Hasil observasi lapangan dan wawancara dengan kelurahan Kereng Bangkirai, untuk meningkatkan daya tahan tubuh, masyarakat lebih memilih mengkonsumsi vitamin dan herbal khas Kalimantan. Masyarakat Kereng Bangkirai juga belum mengetahui manfaat Potok untuk kesehatan sehingga tidak banyak yang berminat menanam maupun membudidayakan tanaman ini.

Berdasarkan analisis situasi dan permasalahan mitra dapat ditawarkan suatu solusi dalam mewujudkan peningkatan imunitas tubuh dengan perbaikan gizi dan pemilihan bumbu masak lokal yang kaya antioksidan serta peningkatan perekonomian keluarga. Peningkatan imunitas tubuh diwujudkan dengan upaya pemberian edukasi tentangvgizi seimbang untuk meningkatkan imunitas tubuh dan khasiat Potok sebagai bumbu kaya antioksidan, ragam olahannya yang dapat menjadi pilihan masakan sehat di masa pandemi Covid-19. Sedangkan peningkatan perekonomian dapat dilakukan dengan upaya pemberian pelatihan berupa keterampilan pemanfaatan lahan pekarangan kepada masyarakat atau keluarga di Kelurahan Kereng Bangkirai mulai dari pemilihan tanaman potok, pengolahan lahan di sekitar rumah hingga penggunaan tanaman potok 
dikonsumsi keluarga di rumah sehingga dapat mengurangi biaya pengeluaran keluarga. Hal ini masih dilakukan dalam skala kecil yakni pada masyarakat di kelurahan Kereng Bengkirai, untuk skala besar masyarakat di kota Palangka Raya.

\section{METODE}

Jumlah peserta yang mengikuti pelatihan sebanyak 20 orang yang dikoordinasi oleh pihak Kelurahan Kereng Bangkirai. Metode yang digunakan dalam kegiatan ini adalah sebagai berikut.

a. Pemberian brosur/leaflet sebagai salah satu media komunikasi dalam menyampaikan informasi tentang Potok beserta khasiat dan cara pengolahannya kepada para peserta kegiatan.

b. Evaluasi dalam bentuk pre test dan post test bagi para peserta. Hal ini dilakukan untuk mengevaluasi tingkat pemahaman peserta terhadap materi yang disampaikan oleh narasumber FK UPR.

c. Penyuluhan

Pemaparan materi terkait cara budidaya, khasiat dan ragam cara pengolahan Potok yang disampaikan oleh narasumber dari Tim Pengabdi FK UPR. Penyuluhan disertai dengan dialog interaktif dengan peserta kegiatan ini.

d. Partisipasi aktif dalam proses pendampingan dan pelatihan budidaya Potok dan pembuatan

e. makanan berbasis Potok untuk membekali keterampilan masyarakat di wilayah Kelurahan Kereng Bangkirai berupa demontrasi pembuatan makanan oleh narasumber dari Tim FK UPR dan praktek mandiri pembuatan makanan yang dilakukan peserta pelatihan. Pada tahap ini peserta pelatihan dibagi menjadi lima kelompok (tiap kelompok beranggotakan 4 orang) dan tiap-tiap kelompok melakukan praktek pembuatan tumis tempe Potok dan sambal Potok.

\section{HASIL DAN PEMBAHASAN}

Hasil dan luaran kegiatan pengabdian kepada masyarakat ini berlangsung dengan lancar di Aula Kelurahan Kereng Bangkirai pada tanggal 27 Oktober 2020. Kegiatan ini dihadiri oleh Kepala Lurah Kereng Bangkirai dan seluruh Tim pengabdian. Peserta yang hadir dalam kegiatan pengabdian sebanyak 20 orang yang merupakan warga dari Kelurahan Kereng Bangkirai.

Kegiatan pengabdian dimulai dengan sambutan dari Kepala Lurah Kereng Bangkirai dan Ketua Tim Pengabdian. Kegiatan pengabdian dimulai dengan beberapa tahapan yaitu tahap persiapan, tahap pelaksanaan dan tahap evaluasi. Adapun uraian dari masingmasing tahapan disajikan sebagai berikut :

\section{Tahap Persiapan}

Sebelum dilakukan pelatihan kepada peserta, diberikan kuesioner yang terdiri atas 7 pertanyaan yang datanya disajikan pada gambar 1.

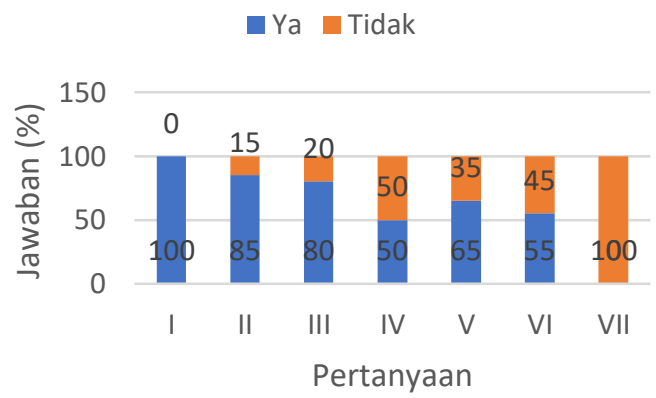

Gambar 1. Hasil kuesioner sebelum kegiatan

Keterangan :

I. Apakah Bapak/Ibu pernah mendengar/ mengetahui tanaman Potok?

II. Apakah Bapak/Ibu pernah mengkonsumsi Potok sebagai bumbu masakan? 
III. Apakah Bapak/Ibu pernah menggunakan Potok sebagai campuran dalam masakan sehari-hari?

IV. Apakah Bapak/ Ibu mengetahui bahwa tanaman Potok memiliki kandungan antioksidan?

V. Apakah tanaman potok memiliki antioksidan yang baik untuk meningkatkan imunitas tubuh?

VI. Apakah Bapak/Ibu pernah melakukan budidaya tanaman Potok?

VII. Apakah Bapak/ Ibu pernah mendapat pelatihan tentang cara budidaya tanaman Potok?

Gambar 1 menunjukkan bahwa peserta kegiatan semuanya sudah mengetahui tanaman Potok, namun sebagian besar belum memanfaatkan Potok dalam makanan seharihari, dan belum mengetahui manfaat serta kandungan antioksidan dalam tanaman Potok. Keseluruhan peserta belum pernah mendapat pelatihan cara budidaya tanaman Potok, hal ini karena belum pernah dilakukan pelatihan dan pendampingan tentang budidaya tanaman Potok.

Pada tahap ini selain kuesioner, peserta juga diberikan pre test untuk mengetahui pengetahuan awal peserta sebelum diberikan pelatihan, yang terdiri atas 5 pertanyaan. Hasil pretest dapat dilihatpada Gambar 2.



Gambar 2. Hasil pre-test sebelum kegiatan
Keterangan :

I. Tanaman Potok bermanfaat bagi kesehatan dan daya tahan tubuh karena mengandung antioksidan

II. Cara penanaman/budidaya tanaman Potok dapat dilakukan menggunakan menggunakan cara stek batang dan tanam biji

III. Penyemaian bibit tanaman Potok sebaiknya diletakkan ditempat teduh sampai bibit mulai tumbuh dan siap dipindahkan ke lahan tanam

IV. Merawat tanaman Potok memerlukan beberapa hal yaitu kecukupan air, sinar matahari dan pemupukan

V. Bagian Potok yang dapat dikonsumsi adalah bagian bunga dan batang

Dari Gambar 2, dapat disimpulkan bahwa pengetahuan awal peserta terhadap tanaman Potok sebanyak $20 \%$ belum mengetahui bahwa Potok mengandung antioksidan, cara menanam dan merawat tanaman Potok 50\% dan 25\% belum mengetahui caranya. Sebanyak 20\% peserta belum mengetahui bagian tanaman Potok yang dapat dikonsumsi.

\section{Tahap Pelaksanaan}

Pada tahap pelaksanaan dilakukan pemberian materi pelatihan yaitu :

a. Materi 1 : Manfaat dan kandungan antioksidan pada tanaman Potok

b. Materi 2 : Ragam olahan Potok

Praktek pengolahan Potok pertama-tama dilakukan demonstrasi cara pembuatan tumis tempe potok kemudian dilanjutkan dengan praktek mandiri, Adapun cara pengolahan yang dilakukan yaitu : tempe mentah 1 papan dipotong dadu, kemudian digoreng setengah matang dan tiriskan. Potok bagian bunga dan batang muda dipotong-potong kecil, terasi secukupnya, bawang merah 3 siung, bawang putih 4 siung diiris tipis, cabe merah 3 biji diiris kecil, gula 
dan garam secukupnya. Kemudian semua bahan ditumis menjadi satu dalam wajan dengan sedikit minyak goreng.

Berdasarkan hasil demonstrasi dan praktek pengolahan Potok, peserta dapat melakukan dengan cukup berhasil dan olahan memiliki rasa yang enak dan wangi.

c. Materi 3 : Keterampilan budidaya Potok

Pelatihan didahului dengan pemberian materi tahapan budidaya Potok, kemudian dilanjutkan dengan pemberian bibit Potok kepada peserta untuk ditanam di pekarangan rumah.

\section{Tahap Evaluasi Akhir}

Setelah kegiatan pelatihan dilakukan, selanjutnya peserta mengisi post test dan kuesioner untuk mengevaluasi tingkat pengetahuan setelah pelatihan dan tingkat keberhasilan kegiatan yang disajikan pada gambar 3 dan tabel 1

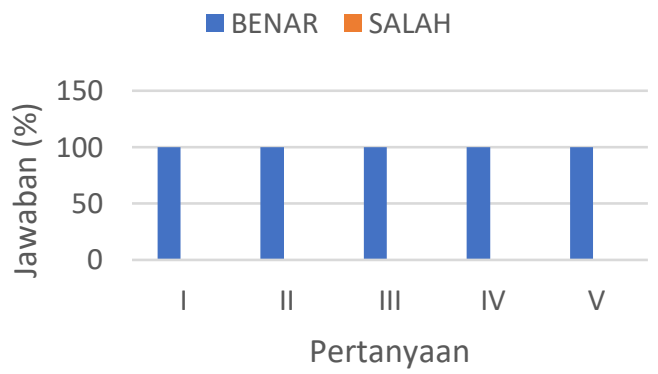

Gambar 3. Hasil postest kegiatan

Keterangan :

I. Tanaman Potok bermanfaat bagi kesehatan dan daya tahan tubuh karena mengandung antioksidan

II. Cara penanaman/budidaya tanaman Potok dapat dilakukan menggunakan menggunakan cara stek batang dan tanam biji

III. Penyemaian bibit tanaman Potok sebaiknya diletakkan ditempat teduh sampai bibit mulai tumbuh dan siap dipindahkan ke lahan tanam

IV. Merawat tanaman Potok memerlukan beberapa hal yaitu kecukupan air, sinar matahari dan pemupukan
V. Bagian Potok yang dapat dikonsumsi adalah bagian bunga dan batang

Berdasarkan hasil postest pada Gambar 3, tampak bahwa terjadi peningkatan pengetahuan peserta $(100 \%)$ setelah dilakukan pelatihan. Sedangkan tingkat keberhasilan kegiatan dapat dilihat pada Tabel 1 .

Tabel 1. Hasil kuesioner setelah kegiatan

\begin{tabular}{|c|c|c|c|}
\hline \multirow[b]{2}{*}{ No } & \multirow[b]{2}{*}{ Pertanyaan } & \multicolumn{2}{|c|}{ Jawaban (\%) } \\
\hline & & $\begin{array}{c}\text { Sudah } \\
\text { jelas }\end{array}$ & $\begin{array}{l}\text { Belum } \\
\text { jelas }\end{array}$ \\
\hline 1 & $\begin{array}{l}\text { Apakah kegiatan } \\
\text { pelatihan yang } \\
\text { dilakukan sudah } \\
\text { jelas? }\end{array}$ & 100 & 0 \\
\hline 2 & $\begin{array}{l}\text { Apakah kegiatan } \\
\text { pelatihan ini } \\
\text { bermanfaat dan } \\
\text { menambah } \\
\text { pengetahuan? }\end{array}$ & 100 & 0 \\
\hline 3 & $\begin{array}{l}\text { Apakah berminat } \\
\text { melakukan budidaya } \\
\text { sendiri di rumah? }\end{array}$ & 100 & 0 \\
\hline 4 & $\begin{array}{l}\text { Apakah berminat } \\
\text { untuk mengkonsumsi } \\
\text { tanaman potok dalam } \\
\text { masakan sehari-hari? }\end{array}$ & 100 & 0 \\
\hline 5 & $\begin{array}{l}\text { Apakah manfaat } \\
\text { tanaman Potok bagi } \\
\text { Kesehatan sudah } \\
\text { dimengerti? }\end{array}$ & 100 & 0 \\
\hline
\end{tabular}

Berdasarkan tabel 1. menunjukkan bahwa peserta kegiatan sudah jelas dengan materi yang disampaikan pada kegiatan pelatihan. Semua peserta turut berperan dengan aktif baik pada tahap awal persiapan kegiatan hingga pada tahap evaluasi akhir. Selama kegiatan peserta menunjukkan antusias dengan diskusi yang interaktif saat pemberian materi. Rata-rata peserta kegiatan menyukai hasil masakan olahan Potok dan akan mencoba lagi di rumah dengan varian berbeda. Peserta juga antusias 
dengan pemberian bibit Potok untuk ditanam di rumah.

Kegiatan pengabdian ini didokumentasikan dalam bentuk video yang kemudian diunggah di Youtube Fakultas Kedokteran Universitas Palangka Raya untuk memenuhi bagian dari luaran kegiatan pengabdian.

\section{KESIMPULAN}

Berdasarkan hasil kegiatan pengabdian yang dilakukan oleh tim Fakultas Kedokteran Universitas Palangka Raya bersama warga Kelurahan Kereng Bangkirai, dapat disimpulkan bahwa pelaksanaan kegiatan ini memberikan kontribusi yang positif dengan adanya peningkatan pengetahuan dan keterampilan pengolahan dan budidaya Potok sebelum dan sesudah pelaksanaan kegiatan. Kegiatan ini memberikan manfaat dan solusi terhadap permasalah yang dihadapi mitra.

Adapun saran untuk kegiatan pengabdian selanjutnya adalah perlunya pembinaan lebih lanjut dari pihak terkait sehingga pengetahuan dan keterampilan yang diperoleh dapat lebih bermanfaat dan menjadi alternatif untuk menjaga kesehatan dengan bahan makanan lokal.

\section{UCAPAN TERIMA KASIH}

Penulis mengucapkan terimakasih kepada Fakultas Kedokteran UPR atas bantuan dana dan Lurah Kereng Bengkirai beserta staf atas kerjasama sehingga kegiatan pengabdian ini dapat berjalan dengan baik dan lancar.

\section{DAFTAR PUSTAKA}

Childs, C. E., Calder, P. C., \& Miles, E. A. 2019. Diet and Immune Function. Nutrients, 11(8):1933.
Cong, L., Mirosa, M., Kaye-Blake, W., \& Bremer, P. 2020. Immune-Boosting Functional Foods: A Potential Remedy for Chinese Consumers Living Under Polluted Air. Business and Management Studies, 6(1), 12-27.

Fristiohady A, Zubaydah WOS, Wahyuni W, Mirda M, Saripuddin S, Andriani R. 2019. Immunomodulator Activity of Effervescent Granule of Wualae Fruit (Etlingera elatior (Jack) R.M. Smith) Based on Specific Phagocytic Activity. Borneo J Pharm. 2(2):35-40.

Ibrahim KS, El-Sayed EM. 2016. Potential role of nutrients on immunity. Int Food Res J. 23(2):464-74

Jackie, T., Haleagrahara, N., \& Chakravarthi, S. 2011. Antioxidant effects of Etlingera elatior flower extract against lead acetate - induced perturbations in free radical scavenging enzymes and lipid peroxidation in rats. BMC research notes, 4, 67

Kementerian Kesehatan RI. 2020. Panduan Gizi Seimbang pada Masa Pandemi COVID-19. Jakarta: Kemenkes RI;p. 32

Kumara A. 2020. Peranan Sistem Kekebalan Tubuh Terhadap Serangan Virus Corona (SARS-CoV-2) pada Manusia. Jakarta; 2020

Lachumy SJT, Sasidharan S, Sumathy V, Zuraini Z. 2010. Pharmacological activity, phytochemical analysis and toxicity of methanol extract of Etlingera elatior (torch ginger) flowers. Asian Pac J Trop Med 3(10):769-74. Available from: http://dx.doi.org/10.1016/S1995$\underline{7645(10) 60185-X}$ 


\section{LAMPIRAN}
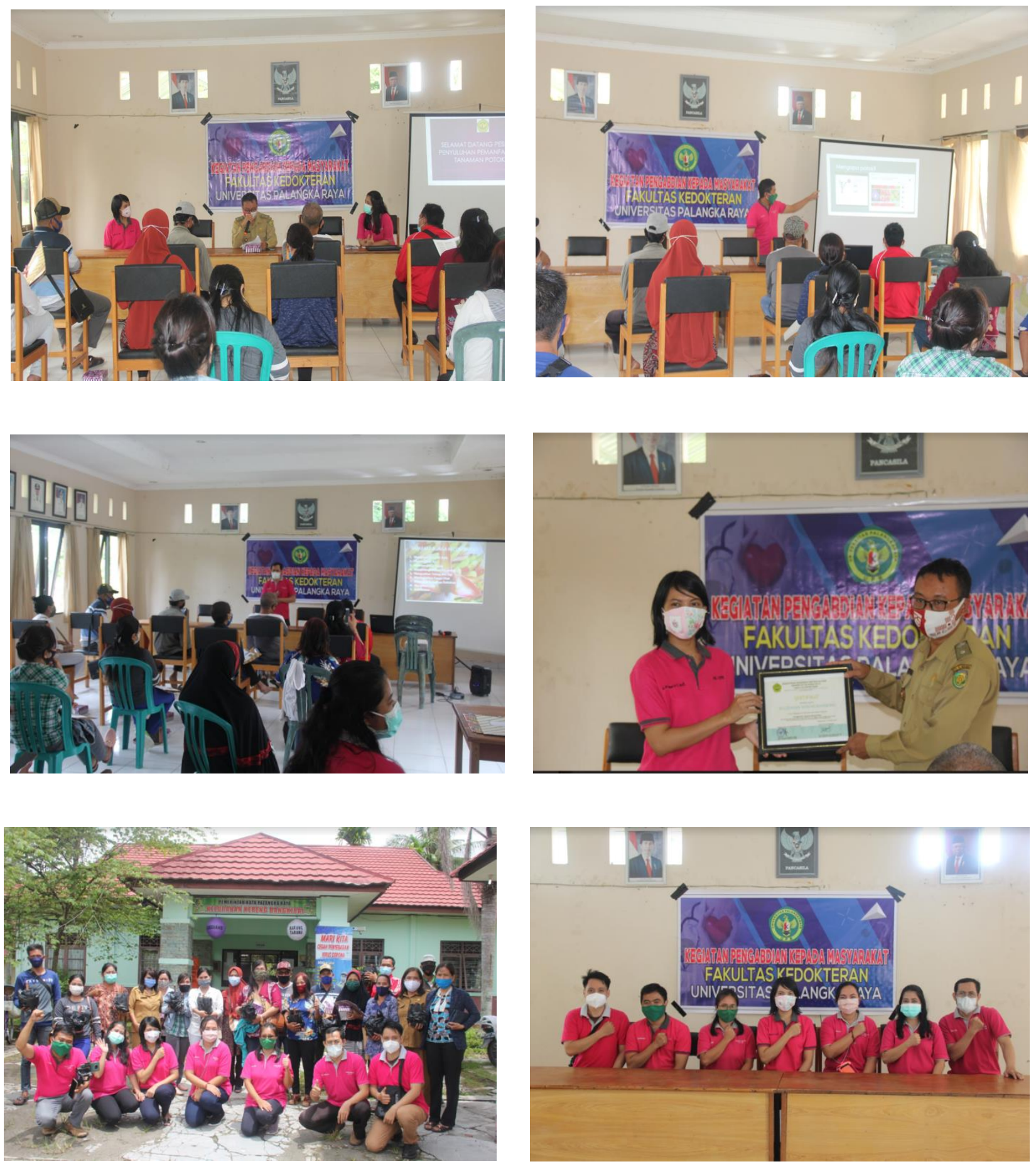